\title{
A construção do personagem no jornalismo esportivo*
}

\section{Building character in sports journalism}

Rafael da Costa Lopes ${ }^{1}$

* Recebido em: 04/05/2015. Aprovado em: 11/09/2015.

1 Rafael Lopes é jornalista formado pelo Centro Universitário de Brasília - UniCEUB e trabalha com jornalismo esportivo desde 2011. Cobriu a Copa das Confederações em 2013 e a Copa do Mundo de 2014 no Brasil. Atualmente é Editor do Globo Esporte em Brasília.

\section{Resumo}

O personagem, de forma semelhante à literatura, quando ator principal de uma reportagem, ocupa papel fundamental no texto jornalístico. Tal e qual nos livros, trata-se de uma componente da construção narrativa que altera e modifica os rumos de uma história. Na presente pesquisa, a observação principal é sobre os personagens do jornalismo esportivo. Especificamente, jogadores de futebol que participaram da Copa das Confederações, realizada no Brasil de 15 a 30 de junho de 2013. Para tratar do papel desses personagens na construção de reportagens nesse período, foi utilizada a análise da narrativa, salientando os movimentos do texto em relação aos "atores do discurso". Na análise, foram separados itens de observação para identificar nuances do processo de construção dessas "pessoas". Uma conclusão é que, para dar sentido à complexidade dos temas, tendo como limitadores o tempo e o formato que se tem para uma notícia na televisão, o jornalismo esportivo reduz o olhar, rotula e impõe a esses personagens, características que permitem ao telespectador criar imagens subconscientes desses atores que extrapolam suas qualidades apenas como jogadores de futebol.

Palavras-chave: Jornalismo esportivo. Construção de personagens. Análise da narrativa. Telejornalismo. Futebol.

\section{Abstract}

The character, similar to literature, where lead actor in a report, occupies a fundamental role in the journalistic text. Just like in the books, it is a narrative construction component that alters and modifies the course of a story. In this research, the main observation is about the characters of sports journalism. Specifically, soccer players who participated in the Confederations Cup, held in Brazil from 15 to 30 June 2013. To address the role of these characters in building reports in this period, analysis of the narrative was used, highlighting the text moves in relation to the "actors of discourse." In the analysis, observation items were separated to identify nuances of the construction process of these "people". One conclusion is that to make sense of the complexity of the issues, having as limiting the time and what you have to format a report on television, sports journalism reduces the look, labels and enforces these characters, features that allow the viewer to create subconscious images of these actors that go beyond its qualities just as soccer players.

Keywords: Sports journalism. Building character. Analysis of narrative. Television. Football. 


\section{Introdução}

Entre 2013 e 2016 o Brasil foi escalado para ser a capital mundial do esporte. Não houve outra oportunidade na história em que o país recebeu tantos eventos esportivos de tamanha grandeza em um espaço tão curto de tempo. Copa das Confederações em 2013, Copa do Mundo em 2014 e Olimpíadas em 2016, são algumas das competições que fizeram e farão desembarcar milhares de atletas e turistas por todo o Brasil. Para o jornalismo, o desembarque é de "personagens", agentes das narrativas que exercem em textos de não-ficção tarefas semelhantes ao que ocorre na literatura. Verificar quais são as características dessas construções no jornalismo esportivo é o objetivo principal deste trabalho.

Nessa segunda década do século 21, a imprensa esportiva brasileira passa por um período de grande oferta de conteúdo que vai ao encontro de uma época onde cada vez mais o cidadão participa ativamente da produção da notícia. Foi-se o tempo em que a fonte só se pronunciava quando era instigada a dar o seu depoimento. Hoje, elas se apropriam de processos e técnicas jornalísticas para fazer com que suas vozes sejam ouvidas. Através da internet, o receptor passou a exercer um papel que antes cabia apenas ao emissor.

Nesse contexto, os novos meios de comunicação e as suas diversas formas de acesso causaram também mudanças na apuração e no formato da produção de uma notícia. Fatos que antes se restringiam a vida particular, hoje são tornados de conhecimento geral através das redes sociais. Esse fenômeno tem transformado eventos comuns do cotidiano particular de diversas pessoas em fatos de interesse de um público cada vez maior.

No mundo esportivo não é diferente. Atletas possuem um apelo midiático comparável a grandes atores de cinema. Jogadores de futebol como o português Cristiano Ronaldo, do Real Madrid da Espanha, que assinou um contrato para receber mais de $\mathrm{R} \$ 50$ milhões por temporada, possuem um alcance midiático global e influenciam desde o corte de cabelo até o modo de agir de pessoas em todo o mundo.

Dessa forma, nos últimos anos, observa-se dentro do Jornalismo Esportivo, o uso frequente de reportagens onde um determinado atleta é a reportagem em si. Seja pela ausência do assunto factual ou pelo esgotamento de pautas, muitos repórteres procuram usar a vida e/ou a carreira esportiva de determinados atletas como lead de suas reportagens. Mas, até que ponto, uma reportagem televisiva, com suas restrições de tempo e imagem, consegue ser abrangente para poder mostrar aspectos verdadeiros da personalidade de uma pessoa?

Diante desse cenário, o objetivo geral deste trabalho é descobrir como são construídos os personagens no jornalismo esportivo. Tentaremos identificar os pontos de congruência e os discrepantes entre a pessoa real e o personagem criado.

Os objetos que constituem esse levantamento são reportagens veiculadas pelo programa Globo Esporte, da TV Globo, no ano de 2013, durante a cobertura da Copa das Confederações.

A presente pesquisa está organizada da seguinte forma: primeiro percorreremos o estudo do jornalismo esportivo, área de interesse deste trabalho, do newsmaking e das Fontes de Informação e Personagens. Após, teremos uma análise crítica do discurso para entender a produção da notícia e a conclusão do trabalho.

\section{Características do jornalismo esportivo}

Falar sobre paixões nunca foi fácil. Além dos poetas, poucos se atrevem a mexer em temas tão sensíveis ao sentimento alheio como o jornalista esportivo. $\mathrm{O}$ problema é que quando apenas as paixões o direcionam, ele deixa de ser jornalista e se transforma apenas em um apaixonado.

A notícia esportiva é o jogo ou a disputa. Delas as pessoas tomam conhecimento assistindo ao espetáculo ou a partir de resumos - os lances principais. Tudo mais é constituído de declarações e decisões, tomadas num clima de paixão, em torno das quais se propõem análises e prognósticos - a crônica desportiva (LAGE, 2001, p. 115).

No início, o jornalismo esportivo no Brasil sempre contou com um certo desprezo de outras editoriais ditas mais nobres. O jornalista, sempre foi o mais fácil de ser identificado em uma redação. Despojado, menos atento as formalidades, das quais quem trabalha em determinadas áreas do jornalismo segue como um mantra. Até porque, para conversar com um jogador de futebol que acabou de correr atrás de uma bola durante 90 minutos, o nível de etiqueta exigida é menor do que o espera um membro do Congresso Nacional. Segundo Li-Chang Shuen Sousa, essas diferenças entre as especialidades dos jornalistas se restringe apenas ao estereótipo.

Como em qualquer produto jornalístico, a sele- 
ção da notícia esportiva é um processo norteado pelos critérios de noticiabilidade universais à atividade de produção e transformação de acontecimentos em fatos noticiáveis. Também no noticiário esportivo tem mais chances de se tornar notícia o que é factual, que desperta o interesse do público, que atinge o maior número de pessoas, que seja inusitado ou curioso, que seja novidade e que apresente bons personagens (SOUSA, 2005, p. 2).

Hoje, a editoria antes relegada aos mais jovens ganhou um status que acompanhou a evolução do esporte e dos consumidores de competições esportivas em todo o mundo. A cada ano, uma legião de "jornalistas apaixonados" desembocam no mercado de trabalho à procura de uma chance naquela editoria antes reservada apenas para eles.

Talvez não haja área do jornalismo tão sujeita a intempéries quanto a cobertura de esportes. O profissional enfrenta o preconceito dos próprios colegas, que a consideram uma editoria menos importante, e também do público, que costuma tratar o comentarista ou repórter esportivo como mero palpiteiro (COELHO, 2004, contracapa).

Por mover bilhões de reais por ano, o mercado esportivo em geral é terreno fértil para falcatruas encontradas em outras áreas da sociedade. Nos últimos anos, coberturas jornalísticas vêm desvendando cada vez mais problemas que envolvem desde gastos públicos mal explicados a subornos de juízes em partidas de futebol. A vigilância exercida pelo jornalismo esportivo à quem faz do esporte um mar de lavagem de dinheiro tem gerado, cada vez mais, uma noção ao grande público de que muitas vitórias esportivas escondem mazelas sociais. Esse conceito vai ao encontro da definição de Nilson Lage sobre outra área do jornalismo, que nesse caso, é ferramenta para descortinar quem faz do esporte sua zona de crime.

O jornalismo investigativo é geralmente definido como forma extremada de reportagem. Trata-se de dedicar tempo e esforço ao levantamento de um tema pelo qual o repórter, em geral, se apaixona. [...] Pode-se também entender o jornalismo investigativo - pelo menos parte dele - como um esforço para evidenciar misérias presentes ou passadas da sociedade, injustiças cometidas; contar como as coisas são ou foram e como deveriam ter sido (LAGE, 2001, p. 138).

Mas o que move grande parte de quem acompanha a cobertura esportiva ainda é a paixão. Seja ela pelo clube, pelo ídolo ou até mesmo pela sua cidade. A pessoa que assiste a um programa esportivo quer saber os porquês das vitórias e os das derrotas. Gostam de ver seus ídolos ainda mais endeusados e seus adversários ainda mais relegados. Ao jornalista esportivo, cabe levar a esse público, informação de relevância e que contribua para a disseminação da prática esportiva, função social implícita a quem milita na área.

Uma tendência no jornalismo contemporâneo que encontra na televisão importância e expressividade ímpares, a valorização do personagem no relato de uma notícia esportiva também é um fator não apenas de reforço da noticiabilidade como de identidade editorial. Ou seja, o noticiário esportivo em televisão se pauta cada vez mais pelos personagens que protagonizam as histórias noticiáveis, sejam eles celebridades ou anônimos (SOUSA, 2005, p. 8).

Para quem acompanha transmissões ao vivo de eventos esportivos, é possível perceber a transformação destes em espetáculos. A forma como narradores, comentaristas e repórteres abordam os assuntos durante os jogos, seja de futebol, vôlei ou qualquer outra modalidade, contribui para que telespectadores, mesmo de longe, se sintam dentro das arenas.

A notícia esportiva se enquadra como mais
um fator de fuga e entretenimento. Barbeiro e
Rangel (2006) afirmam que o jornalismo espor-
tivo tem suas especificidades, pois se confunde,
sempre, com puro entretenimento. Todavia, o
hibridismo entre jornalismo e entretenimento
requer um limite e a atividade jornalística es-
portiva exige uma produção de seus conteúdos
regida por processos técnicos jornalísticos, as-
sim como as outras categorias do meio (MELO;
OLIVEIRA, 2011, p. 2).

O problema real está no exagero dessas abordagens e na ausência de conteúdo propriamente de interesse social. Dar maior destaque ao corte de cabelo de determinado atleta em detrimento a opinião do torcedor sobre as condições dos meios de transporte no entorno do evento vai de encontro ao que podemos definir como "bom jornalismo". O equilíbrio entre o assunto que atrai o telespectador moderno e o serviço devido pelo profissional de comunicação constitui a meta do jornalista esportivo.

\section{A produção noticiosa e o newsmaking}

Para compreender mais sobre a construção do personagem no jornalismo esportivo, é necessário salientar que as produções estão sujeitas a condições, limitações, imposições e formatos de narrativas incorporados pelos meios (tradicionais ou alternativos). Por isso, o estudo do Newsmaking, como teoria do jornalismo, deve refletir sobre as nuances que podem existir quando se decide pela produção de uma reportagem. 
Construir uma realidade através do olhar de quem faz parte dela. Os jornalistas são os responsáveis por mostrar à sociedade o que ela faz, como faz, suas consequências e as opções que ela teria para fazer de forma diferente. Mas esse trabalho passa por um filtro em seu conteúdo, tendo em vista que os próprios jornalistas - e seus credos, anseios, pressões e rotinas - são parte componente desse grupo social que é o seu objeto de trabalho. O conteúdo produzido também sofre um impacto causado pelos critérios estipulados pelo veículo de comunicação na hora de priorizar, seja financeira ou operacionalmente, a realização de uma pauta. Essas condições compõem o modelo teórico do Newsmaking que estabelece uma série de critérios que afetam a construção da realidade pelos jornalistas.

O jornalista está longe de ser o espelho do real. É, antes, a construção social de uma suposta realidade. Dessa forma, é no trabalho da enunciação que os jornalistas produzem os discursos, que, submetidos a uma série de operações e pressões sociais, constituem o que o senso comum das redações chama de notícia (PENA, 2005, p. 128).

No jornalismo esportivo essa realidade não é diferente. Além das pressões sociais já mencionadas, o jornalista lida com sentimentos profundos, nutridos seja por ídolos ou agremiações. Ainda segundo Pena (2005), tal situação cai por terra quando da construção da realidade vista por ele.

O que diminui a pertinência de alguns enfoques conspiratórios na teoria do jornalismo, como, por exemplo, o paradigma da "manipulação da notícia”. Assim, uma suposta intenção manipuladora por parte do jornalista seria superada pelas imposições da produção jornalística. Ou seja, as normas ocupacionais teriam maior importância do que as preferências pessoais na seleção e filtragem das notícias (PENA, 2005, p. 129).

Outra condição importante para o jornalista de esportes diz respeito a estrutura das competições. No mercado atual, eventos têm seus direitos de transmissão vendidos a emissoras. No pacote, entre outras vantagens, as compradoras levam o direito a prioridades em áreas de entrevistas com atletas. Este aspecto, que não impede a cobertura dos resultados e principais destaques, limita as possibilidades de um jornalista de uma emissora que não possui tais direitos conseguir informações mais completas e/ou inéditas e o coloca sob pressão na busca de detalhes que podem reduzir o impacto causado pela restrição no contato com as fontes principais de informação.
Por outro lado, o jornalista que possui livre acesso a essas áreas também sofre uma pressão, só que inversa. Como a empresa investiu para que seus profissionais tivessem direito a livre acesso a atletas e um leque variado de imagens das competições, espera-se um retorno de conteúdo, e consequentemente financeiro, sobre a cobertura do evento. Nesse caso, é recomendando que o profissional acompanhe todo um planejamento realizado pela direção da empresa na busca do melhor retorno em todos os aspectos. Como afirma Pena (2005), apesar de não ser refém da estrutura, o profissional deve respeitar um processo anteriormente pensado na busca da eficiência da cobertura jornalística. Isso é objeto de estudo dessa teoria da produção da notícia.

[...] o processo de produção da notícia é planejado como uma rotina industrial. Tem procedimentos próprios e limites organizacionais. Portanto, embora o jornalista seja participante ativo na construção da realidade não há uma autonomia incondicional em sua prática profissional, mas sim a submissão a um planejamento produtivo (PENA, 2005, p. 129).

Olhando para dentro dessas coberturas, nota-se também um padrão no que diz respeito ao conteúdo das reportagens. Há uma hierarquia clara sobre quais personagens são os mais interessantes de serem abordados, mesmo quando esses critérios fogem da arena esportiva.

A noticiabilidade é negociada por repórteres, editores, diretores e outros atores do processo produtivo na redação. Sua aplicação baseia-se nos valores notícia, que são os tais critérios e operações usados para definir quais acontecimentos são significativos e interessantes para serem transformados em notícia. Por exemplo: a importância do envolvido é um valor-notícia. Quanto mais famoso for o personagem do fato, mas chance este tem de virar notícia. (PENA, 2005, p. 130)

Ao jornalista, cabe sempre ter em mente o valor social do seu trabalho, procurando usar as estruturas oferecidas também em benefício público e não ter como objetivo um sucesso profissional que encontra resultado puramente produtivo.

\section{Fontes de informação e personagens}

As fontes são os olhos do repórter quando eles não presenciaram o fato. É através delas que o jornalista constrói o cenário sobre o qual ele escreve. Ao profissional, cabe sempre levar em consideração alguns fatores que 
podem atrapalhar essa tentativa de leitura da realidade, como explica Pena (2005).

A fonte de qualquer informação nada mais é do que a subjetiva interpretação de um fato. Sua visão sobre determinado acontecimento está mediada pelo "óculos" de sua cultura, sua linguagem, seus preconceitos. E, dependendo do grau de miopia, a lente de aumento pode ser direcionada para seus próprios interesses (PENA, 2005, p. 57).

Uma câmera digital, um tablet ou um celular. Com qualquer desses equipamentos, uma pessoa pode produzir conteúdo que poderá ser aproveitado em um telejornal. Essa posição ativa de quem antes só falava quando era instigado tem mudado um relacionamento entre jornalistas e fontes, que funcionava apenas em uma via, como definiu Lage (2001). É tarefa comum dos repórteres selecionar e questionar essas fontes, colher dados e depoimentos, situá-los em algum contexto e processá-los segundo técnicas jornalísticas (LAGE, 2001, 49).

Com o suporte da internet, a fonte tomou para si, processos antes usados apenas pelo profissional de jornalismo. Ligar para as redações para informar sobre um cano de esgoto estourado que deixou a rua inteira sem água vem sendo cada vez mais substituído por simplesmente usar o celular, filmar o buraco e postar o vídeo em uma rede social junto com os dados de desde quando o buraco está aberto, quantas vezes os moradores ligaram para os órgãos responsáveis e não foram atendidos e etc.

Esse modelo de comunicação é próximo ao observado durante o surgimento do próprio repórter, como relata Schmitz.

A figura do repórter, por exemplo, surge por volta de 1870, por se caracterizar no tipo de jornalista que buscava a notícia (newsgathering), tomava notas sobre os eventos e considerava os fatos. Até então os jornalistas não perguntavam as fontes, apenas relatavam o ocorrido e emitiam suas opiniões pessoais (SCHMITZ, 2011, p. 8).

A partir dessa facilidade na divulgação de informação, pessoas comuns passaram a ter suas vidas expostas como antes eram apenas pessoas públicas. Cada vez mais a narrativa jornalística tem se aproveitado de personagens que ganham força devido a facilidade do público em conhecer a vida dessas pessoas pela internet.

Manifestada sob a espécie de um conjunto descontínuo de marcas, a personagem é uma unidade difusa de significação, construída progressivamente pela narrativa. Uma personagem é pois o suporte das redundâncias e das transformações semânticas da narrativa, é constituí- da pela soma das informações facultadas sobre o que ela é e sobre o que ela faz (HAMON apud REIS, 1994, p. 315).

Portanto, quando da construção do personagem, mais do que o recorte da história a ser contado, tem relevância a forma como o jornalista conduz a reportagem e o que de importante e relevante para quem o assiste ele tenha dito. O resultado desse processo de construção da narrativa formará o perfil do personagem que será apresentado para o telespectador.

\section{Procedimentos metodológicos: análise da narrativa}

Para tentar entender como são formados os personagens dentro do jornalismo esportivo, foi usado, como caminho de pesquisa, a análise da narrativa jornalística (Narratologia) em relação ao movimento desses agentes do discurso no texto. Muito embora o autor não indique considerar os procedimentos como um guia fechado de análise, a reflexão ajuda a compreender a dinâmica dos mesmos dentro da narrativa. Da mesma forma, o autor estipula que o pesquisador deve adaptar o objeto ao método de observação.

Os discursos narrativos se constroem através de estratégias comunicativas e recorrem a operações linguísticas e extralinguísticas para operar certas intenções e objetivos, realizam-se em contextos pragmáticos e produzem certos efeitos (MOTTA, 2005, p. 37).

De acordo com o autor, a comunicação narrativa geraria relação entre os interlocutores: o narrador investe na organização narrativa do seu discurso e solicita uma determinada interpretação de parte do seu destinatário.

As análises da narrativa jornalística podem destacar os personagens, pois foca sua observação na história contada e não apenas no discurso.

No jornalismo as personagens costumam ser fortemente individualizadas e transformar-se no eixo das histórias. Os designantes das personagens, tais como nomes, identificadores e co-referências devem ser particularmente observados. Porém, é importante lembrar que mesmo na narrativa realista do jornalismo as personagens são figuras de papel, ainda que tenham correspondentes na realidade histórica (MOTTA, 2005, p. 7).

Com isso, este procedimento de observação, definido de forma limitada a atender o período curto de pesquisa, permite uma interpretação do simbolismo criado quando da criação de reportagens tendo como persona- 
gens pessoas que possuem parte de suas vidas conhecidas pelo grande público. É possível ainda uma maior facilidade na percepção das metanarrativas, pois o contexto de publicação dessas reportagens, implica uma abordagem factual de um assunto passado. Entretanto, Motta faz uma ressalva para este tipo de procedimento:

Deve-se, portanto, evitar a análise do tipo psicologista ou social da personagem e concentrar a atenção na observação de sua representação como figura do discurso jornalístico, observar como o narrador imprime no texto marcas com as quais pretende construir a personagem na mente dos leitores / ouvintes (MOTTA, 2005, p. 96).

Essas marcas no texto, conforme aborda Motta (2005), foram o guia para a observação na pesquisa. Destarte, o uso da análise da narrativa jornalística como ferramenta permitirá compreender como são criadas e quais artifícios são usados por quem conta a história, o jornalista.

Foram escolhidas cinco reportagens veiculadas no programa Globo Esporte, da Rede Globo de Televisão, no período de 15 de junho de 2013 até 30 de junho de 2013, datas respectivamente, do jogo de abertura e da final da Copa das Confederações de 2013. O programa foi transmitido em edição única para todo o Brasil. As reportagens escolhidas foram as que possuíam um jogador da seleção brasileira como personagem central. A amostra é a seguinte:

A. Jô, “O Predestinado” (Veiculada em 17/06/2013, com dois minutos e quarenta e dois segundos. Repórter: Tino Marcos. Link: http://bit.ly/1Ey$0 \mathrm{gKC})$

B. Luiz Gustavo, "O Invisível” (Veiculada em 18/06/2013, com dois minutos e quarenta segundos. Repórter: Eric Faria. Link: http://bit. ly/1Iu5ha2)

C. Hulk, "O Forte” (Veiculada em 19/06/2013, com dois minutos e vinte e três segundos. Repórter: Tino Marcos. Link: http://bit.ly/1GKHu3p)

D. Fred, “O Invicto” (Veiculada em 21/06/2013, com um minuto e quarenta segundos. Repórter: Mauro Naves. Link: http://bit.ly/1JEZ1gU)

Para cada uma delas, a partir dos preceitos descritos por Motta (2005), este pesquisador criou cinco itens de observação, a fim de identificar nesse contexto, de forma preliminar, os movimentos da narrativa.

1) Adjetivos que demonstram traços de personalidade;
2) Uso de outras fontes além do entrevistado;

3) Participação do personagem na reportagem;

4) Informações da Passagem; e

5) Desfecho da reportagem.

Este método visa a tentar entender como são formados os personagens dentro do jornalismo esportivo e busca, nos artifícios da narrativa criada pelos repórteres, sinais que identifiquem sua caracterização dentro do discurso, conforme chama a atenção Motta. Na semiótica estruturalista a personagem perdeu força enquanto categoria de análise. Centrando-se na história, não no discurso, a narratologia recupera a sua importância (MOTTA, 2005, p. 94).

O uso da análise da narrativa como procedimento metodológico para a desconstrução do personagem jornalístico ainda é raro. Em sua grande maioria, ela é usada para análise de personagens literários. Porém, a narratologia pode ser aplicada ao tomarmos como base que na narrativa jornalística, o repórter sempre tenta ilustrar e confirmar as características já conhecidas do personagem, sendo as ferramentas utilizadas para isso, passíveis de análise.

\section{Análises e resultados}

Conforme trazido no capítulo anterior, para facilitar a análise das reportagens selecionadas, dividimos cada observação nos cinco tópicos a seguir. Em cada um deles, além da observação, existe um recorte do texto completo com marcações em negrito de trechos que ilustram a análise.

\subsection{Adjetivos que demonstram traços de persona- lidade}

Um adjetivo sempre faz parte do fio condutor da história. Seja ele um traço da personalidade ou um momento vivido pelo personagem. Porém, a presença dele no texto, nem sempre é encontrada. Na reportagem Fred, “O Invicto", por exemplo, os repórteres deixam sempre subentendido essa parte do fio da história, mas não o expressam diretamente.

No trecho abaixo da reportagem Jô, “O Predestinado” (2013), o repórter diz que o atleta é desinibido. Concluiu ainda que ele sempre esteve "à vontade" no grupo de jogadores da seleção brasileira.

Off: desde que chegou, se mostrou desinibido, à vontade no grupo [...] aos vinte e seis anos, está 
dando uma daquelas voltas que a vida e o futebol dão. [...] era reserva de Leandro Damião no internacional. [...] foi dispensado do Inter. por causa do Leandro Damião, que ele hoje substitui na seleção (MARCOS apud JÔ, O PREDESTINADO, 2013).

$\mathrm{Na}$ reportagem Luiz Gustavo, “O Invisível” (2013), o adjetivo é encontrado em uma frase do próprio atleta, que se julga uma pessoa tímida. Conhecida no íntimo apenas pela própria família. "como você disse, eu não apareço muito. [...] até mesmo na minha vida pessoal. [...] eu acho que quem me vê mesmo são as pessoas que estão próximas de mim."

Em Hulk, “O Forte” (2013), o repórter usa uma imagem em câmera lenta que destaca os músculos do atleta e na sequência afirma que ele é humilde. Compara a força física com a modéstia do personagem. Na sequência, conclui sobre a personalidade humilde do atleta.

Off: a imagem é lenta e impressionante: explosão muscular em fartos detalhes. [...] Hulk. [...] o mais forte é também um dos mais humildes. [...] o que tem de tamanho tem de modéstia.

Off: [...] mas não há vestígio de marra naquele metro e oitenta, naqueles noventa quilos (HULK, O FORTE, 2013).

\subsection{Uso de outras fontes de informação}

A análise deste item evidenciou uma ausência de correspondências mais claras entre as fontes ouvidas durante a construção do personagem. Quando suas falas são usadas, cumprem apenas um papel de "escada" para corroborar a tese principal da reportagem. Não foi possível observar que, sabendo que se tratava da construção de um personagem, ela opinasse de forma espontânea e produzisse um relato mais completo.

Na reportagem Hulk, “O Forte” (2013), os repórteres não utilizaram nenhuma outra fonte de informação, a não ser o próprio personagem.

Em Jô, “O Predestinado” (2013), o repórter usa uma fala do treinador da seleção brasileira, Luiz Felipe Scolari (Felipão), para confirmar o bom momento vivido pelo atacante. "É um bom jogador, de pé esquerdo é difícil de ser marcado, tá aproveitando a chance pra colher agora e mais na frente" (SCOLARI, 2013 apud JÔ, O PREDESTINADO, 2013).

$\mathrm{Na}$ reportagem Luiz Gustavo, “O Invisível” (2013), o repórter utiliza uma fala da mesma fonte para confirmar a condição do jogador como titular da equipe. Artifício idêntico ao utilizado na reportagem anterior.
"Eu acho que ele foi dos melhores jogadores, dentro do contexto do jogo" (SCOLARI, 2013 apud LUIZ GUSTAVO, O INVISÍVEL, 2013).

Diferentemente da reportagem Fred, “O Invicto" (2013), onde é empregada a fala do coordenador técnico da seleção para destacar que o atleta não está sofrendo pressão pela ausência de gols e de que ele conta com a confiança da comissão técnica. "Não podemos colocar pressão [...] goza da confiança da comissão técnica" (PARREIRA, 2013 apud FRED, O INVICTO, 2013).

\subsection{Participação do personagem na reportagem}

Em todas, o ator principal fala sobre si e sempre de acordo com o eixo narrativo proposto durante toda a reportagem.

Em Jô, “O Predestinado” (2013), o repórter utiliza duas frases do personagem. Em todas, o atleta, relata o momento vivido no campeonato.

Fica marcado, passa um filme de tudo o que você passou na carreira, familiares, amigos, é uma emoção muito boa, só quem fez um gol pela seleção sabe o que é.

Estão sendo 8 dias maravilhosos, nunca vivi outra coisa parecida, tinha programado uma viagem com a minha esposa, ai surgiu essa oportunidade, mas Deus me iluminou e tenho que aproveitar (JÔ, O PREDESTINADO, 2013).

$\mathrm{Na}$ reportagem Luiz Gustavo, “O Invisível” (2013), o repórter utiliza quatro frases do personagem. Nelas, o atleta fala de sua função tática e do seu estilo mais discreto.

Pra mim não é sacrifício nenhum, pra mim é um prazer estar podendo fazer com que os meus companheiros que tem mais características ofensivas possam fazer o jogo e a gente possa conseguir sair com a vitória.

$\mathrm{Eu}$ procuro fazer o simples, procuro, sei que a minha função dentro de campo é muito importante pra ajudar os companheiros.

Se pra isso eu tiver que correr e roubar bola pros outros é isso que eu vou fazer com o maior prazer.

Como você disse, eu não apareço muito [...] até mesmo na minha vida pessoal [...] eu acho que quem me vê mesmo são as pessoas que estão próximas de mim (LUIZ GUSTAVO, O INVISÍVEL, 2013)

Em Hulk, “O Forte” (2013), o repórter usa duas frases do personagem. Nelas, o atleta fala do seu agradecimento pelas conquistas e das vantagens do seu porte físico. 
No momento que entro em campo, como qualquer companheiro, é um momento de agradecer a Deus por estar vestindo a camisa da seleção brasileira.

Acham que sou grande forte, trombador, achavam que era um nove, de área, mas as pessoas me veem fora do normal [...]. Aproveito a força, é importante no futebol, tem que saber aprovei$\operatorname{tar}$ (HULK, O FORTE, 2013).

Na reportagem Fred, “O Invicto” (2013), o repórter utiliza três frases do personagem. Em todas, o atleta destaca a vontade de fazer gols no campeonato.

Quero fazer gol em todos os jogos. [...] Se der pra fazer mais de um, melhor ainda.

Incomoda. Incomoda um pouquinho mas sei que faz parte. Sei que tem coisas guardadas pra frente.

Vamos esperar contra a Itália, jogos mais importantes, semifinal e final. [...] Fazer gols importantes aí. [...] Mas eu estou feito um louco procurando o gol (FRED, O INVICTO, 2013).

\subsection{Informações da passagem}

Nesse item, há um consenso. Em todas, é possível observar que o repórter faz uma conclusão sobre os fatos narrados até o momento e depois cria uma expectativa para uma nova característica do personagem. Ou seja, utilizam a Passagem como um ponto de transição na reportagem.

Em Jô, “O Predestinado” (2013), o repórter destaca a origem humilde da maioria dos jogadores da seleção brasileira e faz uma alusão ao fato, desse tipo de pessoa, sempre aproveitar a chances que lhe são dadas, assim como o personagem. Passagem: "a história e a vida da maioria dos convocados é a do menino pobre que venceu rápido no futebol e na vida. [...] muitas vezes porque aproveitou bem uma oportunidade chave. [...] tipo o Jô" (JÔ, O PREDESTINADO, 2013).

$\mathrm{Na}$ reportagem Luiz Gustavo, “O Invisível” (2013), o repórter exalta as qualidades técnicas e físicas do personagem e encerra com uma avaliação de personalidade que serve como introdução a opinião do atleta a respeito de seus sucessos. "Mas que corre. [...] muito [...] sábado, foram onze quilômetros. [...] ninguém correu tanto quanto ele. [...] roubou cinco bolas e só fez uma falta. [...] disposição. [...] fôlego. [...]e humildade. [...]”.

Na reportagem Hulk, “O Forte” (2013), o repórter descreve os traços físicos do personagem. Depois, conclui que a maioria das pessoas o vê como uma pessoa sem o perfil de jogador técnico. E encerra antecipando que o atleta não concorda com esse diagnóstico.

Camisa tamanho g e calção extra-grande. [...] Hulk é diferente até na dimensão do uniforme. Que mesmo assim parece apertado. Há quem veja os traços físicos dele e sentencie: trombador. [...] não é assim que ele se sente (HULK, O FORTE, 2013).

Em Fred, “O Invicto" (2013), o repórter aponta como o personagem têm buscado comprovar sua capacidade para ser titular da seleção brasileira. "[...] e para corresponder a essa confiança que recebe da comissão técnica, Fred tem a fórmula: mostrar o seu valor nos jogos decisivos.

\subsection{0 desfecho da reportagem}

As características do desfecho também são comuns em todas as amostras. Sempre baseado no eixo narrativo proposto, o repórter deixa para o telespectador uma informação que é conclusiva, mas com brechas para novas histórias. Ele confirma a ideia inicial que propõe uma característica peculiar ou uma situação momentânea para o personagem, e, ao mesmo tempo, dá um ar de transitoriedade sobre o que esperar dele.

Na reportagem Jô, “O Predestinado” (2013), o repórter conclui lembrando o nome verdadeiro (o atleta é mais conhecido pelo apelido) e fatos recentes na carreira do atleta. E termina destacando que a condição de reserva da seleção brasileira, pode ser passageira. off: "João de Assis, paulista revelado pelo Corinthians, atacante de sucesso no Atlético Mineiro. [...] o titular é Fred, não se discute. [...] mas ele hoje tem um reserva em alta".

Em Luiz Gustavo, “O Invisível” (2013), o repórter conclui destacando que o estilo do atleta de passar despercebido é uma vantagem para ele e para a própria seleção brasileira. off: "todo time tem os seus protagonistas e os seus coadjuvantes. [...] Luiz Gustavo, o invisível que faz os companheiros aparecerem".

Na reportagem Hulk, “O Forte” (2013), o repórter encerra comparando o personagem com outro atleta, que ele afirma e demonstra com imagens ser admirado pela torcida, e usa uma metáfora relacionando a parte física do personagem com a confiança da comissão técnica da seleção no trabalho realizado por ele. off: "Lucas pode até ser um queridinho da torcida, mas Hulk está sempre tranquilo: a enorme batata dele não está assando".

Em Fred, “O Invicto” (2013), o repórter encerra com o atleta complementando a Passagem, na qual ele 
destaca a confiança da comissão técnica na capacidade dele em fazer gols. "vamos esperar contra a Itália, jogos mais importantes, semifinal e final. [...] fazer gols importantes aí. [...] mas eu estou feito um louco procurando o gol. [...] o torcedor espera que ele ache o quanto antes".

\section{Conclusão}

Em 10 de abril de 1921, em uma coluna intitulada "Traços a Esmo" no jornal "O Índio", que circulava na cidade de Palmeira do Índio (AL), Graciliano Ramos, sob o pseudônimo de J.Calisto, escreveu o seguinte:

Pensa-se em introduzir o futebol, nesta terra. É uma lembrança que, certamente, será bem recebida pelo público, que, de ordinário, adora as novidades. Vai ser, por algum tempo, a mania, a maluqueira, a ideia fixa de muita gente. Com exceção talvez de um ou outro tísico, completamente impossibilitado de aplicar o mais insignificante pontapé a uma bola de borracha, vai haver por aí uma excitação, um furor dos demônios, um entusiasmo de fogo de palha capaz de durar bem um mês. [...] Estrangeirices não entram facilmente na terra do espinho. O futebol, o boxe, o turfe, nada pega. Desenvolvam os músculos, rapazes, ganhem força, desempenem a coluna vertebral. Mas não é necessário ir longe, em procura de esquisitices que têm nomes que vocês nem sabem pronunciar. Reabilitem os esportes regionais que aí estão abandonados: o porrete, o cachação, a queda de braço, a corrida a pé, tão útil a um cidadão que se dedica ao arriscado ofício de furtar galinhas, a pega de bois, o salto, a cavalhada e, melhor que tudo, o cambapé, a rasteira (CALISTO apud FRAGA, 2013).

Ainda hoje, paira uma dúvida se no texto existia uma ironia velada ou um ataque de ufanismo do jornalista e escritor, autor de Vidas Secas (1938), uma das maiores obras da literatura brasileira. Porém, podemos dizer que, em relação ao esporte bretão, ele errou feio. Brasil e futebol são quase que sinônimos em todo o mundo. O tamanho da comoção que a realização da Copa do Mundo de 2014, em terras tupiniquins, criou, nos dá a medida da importância esportiva e principalmente social que o futebol tem sobre nosso país.

Esse peso que o futebol possui na sociedade brasileira é o parâmetro guia para sabermos o quanto os personagens dentro do jornalismo esportivo são importantes. Nos exemplos analisados, é possível perceber que o repórter sempre utiliza como fio condutor características que estejam mais evidentes no momento da produção da reportagem. A personalidade completa da pessoa física dá lugar a uma representação factual do atleta. Ou seja, traços que mais se destacam durante a cobertura ou que estejam em maior evidência na crônica esportiva ou nas redes sociais. Torna-se a própria representação do atleta o eixo da história. A pessoa física dá lugar a um personagem moldado pelo repórter.

Alguns dos motivos que podem levar os repórteres a fazerem de um recorte de personalidade o assunto principal da reportagem são: a duração da cobertura, o limite de tempo no telejornalismo, às dificuldades de conseguir uma variedade grande de imagens no curto espaço de tempo entre a produção e a edição e até mesmo o problema de se esgotar as facetas de um atleta que poderá ser, em uma outra reportagem, mais uma vez, o seu eleito como eixo narrativo.

As reportagens focadas apenas em um atleta deixam claro também um fator existente em todos os esportes, sejam eles coletivos ou individuais, que é o interesse do público em conhecer quem são os atores principais das modalidades que eles amam. A busca sobre informações que extrapolem suas atividades dentro dos campos ou das quadras cria um nicho importante de atuação para o jornalista, que também é um escritor, mas que constrói personagens de carne e osso.

\section{Referências}

BARBEIRO, Heródoto; RANGEL, P. Manual do jornalismo esportivo. São Paulo: Contexto, 2006.

COELHO, Paulo Vinícius. Jornalismo esportivo. São Paulo: Contexto, 2004.

FRAGA, Plínio. A rasteira de Graciliano Ramos no futebol. 2013. Disponível em: $<$ http://bit.ly/1IbOUQg $>$. Acesso em: 28 out. 2015.

FRED, O INVICTO. Globo Esporte. Repórter: Mauro Naves. Rio de Janeiro: Rede Globo, 21 jun. 2013. Programa de TV. Disponível em: <Link: http://bit.ly/1JEZ1gU> . Acesso em: 28 out. 2015.

HULK, O FORTE. Globo Esporte. Repórter: Tino Marcos. Rio de Janeiro: Rede Globo, 19 jun. 2013. Programa de TV. Disponível em: <http://bit.ly/1GKHu3p >. Acesso em: 28 out. 2015.

JÔ, O PREDESTINADO. Globo Esporte. Repórter: Tino Marcos. Rio de Janeiro: Rede Globo, 17 jun. 2013. Programa de TV. Disponível em: <Link: http://bit.ly/1Ey$0 \mathrm{gKC}>$. Acesso em: 28 out. 2015. 
LAGE, Nilson. A reportagem: teoria e técnica de entrevista e pesquisa jornalística. Rio de Janeiro: Record, 2001.

LUIZ GUSTAVO, O INVISÍVEL. Globo Esporte. Repórter: Eric Faria. Rio de Janeiro: Rede Globo, 18 jun. 2013. Programa de TV. Disponível em: <http://bit.ly/1Iu5ha2>. Acesso em: 28 out. 2015.

MELO, T. S. Jornalismo esportivo no Brasil. In: OLIVEIRA, A. B. A comédia em destaque no telejornalismo esportivo da Rede Globo: por Tadeu Schmidt e Tiago Leifert. XXXIV Congresso Brasileiro de Ciências da Comunicação, 2011.

MELO, T. S.; OLIVEIRA, A. B. A comédia em destaque no telejornalismo esportivo da Rede Globo por Tadeu Schmidt e Tiago Leifert. In: CONGRESSO BRASILEIRO DE CIÊNCIAS DA COMUNICAÇÃO, 34, 2011, Recife. Anais eletrônicos... Disponível em: <http://www.intercom.org.br/papers/nacionais/2011/resumos/R6-0263-1. pdf>. Acesso em: 28 out. 2015.
MOTTA, Luiz Gonzaga. Narratologia: teoria e análise da narrativa jornalística. Brasília: Casa das Musas, 2005.

PENA, Felipe. Teoria do jornalismo. São Paulo: Contexto, 2005.

REIS, Carlos. Dicionário de narratologia. Coimbra: Almedina, 1994.

SCHMITZ, Aldo Antonio. Fontes de notícia: ações e estratégias das fontes no jornalismo. Florianópolis: Combook, 2011.

SOUSA, Li-Chang Shuen C.S. Cobertura esportiva na televisão: critérios de noticiabilidade na interface entre jornalismo e entretenimento. 2005. Disponível em: <http:// bit.ly/1KaqfsF>. Acesso em: 28 out. 2015.

SOUSA, LI-Chang Shuen Cristina Silva. Noticiário esportivo no Brasil: uma resenha histórica. Pernambuco: UFP, 2006. 